$12-2018$

\title{
Holding Back the Tide: Genocide Prevention in Our More Violent World
}

Alex J. Bellamy

University of Queensland

Follow this and additional works at: https://digitalcommons.usf.edu/gsp

\section{Recommended Citation}

Bellamy, Alex J. (2018) "Holding Back the Tide: Genocide Prevention in Our More Violent World," Genocide Studies and Prevention: An International Journal: Vol. 12: Iss. 3: 10-19.

DOI:

https://doi.org/10.5038/1911-9933.12.3.1563

Available at: https://digitalcommons.usf.edu/gsp/vol12/iss3/6

This Conference Proceeding is brought to you for free and open access by the Open Access Journals at Digital Commons @ University of South Florida. It has been accepted for inclusion in Genocide Studies and Prevention: An International Journal by an authorized editor of Digital Commons @ University of South Florida. For more information, please contact digitalcommons@usf.edu. 


\title{
Holding Back the Tide: Genocide Prevention in Our More Violent World
}

\author{
Alex J. Bellamy \\ University of Queensland \\ Brisbane, Australia
}

The field of genocide studies has achieved much in its relatively short lifetime. As a result, we have a much better understanding of genocide - that problem from hell - today than we did just a few years ago. Genocide research has helped demystify this crime of crimes. We understand its causes, its triggers and its processes of escalation much better than we once did. We understand how individual agency and local conditions can profoundly influence patterns of violence. Today, there are far fewer cases of genocide and mass killing hidden from view than there once was. New stories of victims once unknown come to light with each passing year. Their voices, once silenced, speak to us with fresh clarity thanks to the painstaking work of the genocide researcher.

As a result of these endeavors, we have a much better understanding of how genocide can be prevented and vulnerable populations protected. Combined with the activism of key individuals, governments and international organizations, this knowledge helped give rise to what I have described elsewhere as an 'international human protection regime' - a complex of norms, institutions and practices focused on the minimization of suffering resulting from war, atrocities and genocide. ${ }^{1}$ Combined with other structural forces - the spread and consolidation of modern states, industrialization, economic growth and trade, and the social liberalization that often accompanied them - this international regime has contributed to a significant decline in the incidence of organized violence, including of genocide over the past few decades.

Recognizing this fact, just a few years ago, a flurry of new books declared that humanity was 'winning the war on war'; that our 'better angels' were making societies ever more peaceful; that we could hope how to eliminate genocide and mass atrocities 'once and for all.' ${ }^{2}$ After the tumult of the immediate post Cold War period - and the genocides in Rwanda and Bosnia - the tide, it seemed, had turned against genocide. International activism in support of peace and structural forces unleashed modernization and globalization were having a decisive impact. If not the end of history, then perhaps, the beginning of the end of genocide's history.

But for all the progress that was made in building barriers against genocide - and we should not shy away from acknowledging that significant progress was indeed made - we find ourselves facing a major problem. History is taking its revenge. Since the start of the 'Arab Spring' in early 2011, global trends in mass violence have moved consistently in the wrong direction. The number of armed conflicts has increased. Some reports suggest a six hundredfold increase in the annual number of civilian casualties in war. Atrocity crimes are committed with increasing regularity. Perpetrators exhibit a confidence bred of impunity. Forced displacement - both internal and international - has reached levels not seen since the end of the Second World War.

The basic fact of increasing mass violence is not our only problem. Wherever we look, the forces that promoted human rights, human dignity and human protection and the sense of our common humanity that gave rise to mutual aid are in seeming retreat. Meanwhile, the forces of racism, xenophobia, nationalism, and what Martin Ceadal called "warism" - ideas that are the very life blood of genocide - seem to be everywhere on the march. ${ }^{3}$

Today, we confront a global crisis in which the progress we have made in winding back the tyranny of genocide is being unraveled. Unless urgent action is taken to address the crisis, we risk repeating the mistakes of our more violent past. The stakes could not be higher. If we fail to mount

\footnotetext{
${ }^{1}$ Alex J. Bellamy, “The Humanization of Security: Towards an International Human Protection Regime," European Journal of International Security 1, no. 1 (2016), 112-133.

${ }^{2}$ Joshua S. Goldstein, Winning the War on War: The Decline of Armed Conflict Worldwide (New York: Dutton, 2011); Steven Pinker, The Better Angels of our Nature: Why Violence has Declined (New York: Penguin, 2012); Gareth Evans, The Responsibility to Protect: The Campaign to End Mass Atrocities Once and for All (Washington, DC: The Brookings Institution, 2008).

${ }^{3}$ Martin Ceadal, Thinking about Peace and War (Oxford: Oxford University Press, 1987).
}

Alex J. Bellamy. "Holding Back the Tide: Genocide Prevention in Our More Violent World" Genocide Studies and Prevention 12, 3 (2018): 10-19. @2018 Genocide Studies and Prevention. 
a successful challenge to the march of mass violence, our world will continue to become more unstable, more divided, and more violent. What states, international institutions, and global civil society do next will be, quite literally, a matter of life and death for the world's most vulnerable populations.

In this lecture, I want to examine this global crisis and enquire into its causes and consequences. I also want to suggest some steps that can be taken to turn the tide. I want to argue that although the struggle against genocide and mass atrocities is today confronting an acute crisis, there are grounds for thinking that determined action can hold back the tide of hate. This can be done by reinvigorating global politics based on fundamental human rights, collective action and accountability.

\section{Winning the War on Genocide}

I should start, though with a few words on the barriers erected against genocide in the decades following the Holocaust - barriers that became a comprehensive international regime for human protection only in the past two decades. Through Nuremberg, Tokyo, the Eichmann trial and other legal innovations, the Holocaust left an indelible marks on world politics: the notions that individuals and groups had 'basic' or 'fundamental' rights arising out of their very humanity that transcended the sovereign rights of states and that state agents, even political leaders, should be held criminally liable serious violations of those rights. In the decades that followed, significant normative, political and institutional progress was made to actualize that ideal. An International Human Protection regime emerged to give meaning to this ideal. It evolved from at least eight interconnected streams of norms, rules, practices and institutional developments that emerged, in a variegated way, in response to different aspects of civilian suffering in times of war, genocide and mass atrocities. These were:

One: The elaboration of legal rules governing basic conduct in world affairs: principles of nonaggression and non-interference to protect weak states from predation by the strong and eliminate armed aggression; principles of anti-imperialism and national self-determination that prevented strong states translating military successes into legitimated territorial gains.

Two: The development and extension of international humanitarian law, principally the articulation and prohibition of genocide, crimes against humanity and war crimes, and including recent efforts to prohibit indiscriminate weapons (land mines, cluster munitions, nuclear weapons) and the transfer of arms to actors who may use them to commit atrocity crimes (arms trade treaty). These rules, now considered customary and jus cogens - in that they apply to all states and no derogation is possible - established individuals and groups as the bearers of fundamental rights that could not, under any circumstance, be violated.

Three: The establishment of positive legal, political and moral duties to extend protection against these crimes across national borders. All States have an extraterritorial obligation to take all reasonable measures to prevent genocide. They have an additional responsibility to raise the alarm when genocide is committed or imminently apprehended by bringing the matter to international attention.

In relation to war crimes, Common Article 1 of the 1949 Geneva Conventions points to an obligation not just to abide by the law but to "ensure respect" for the Conventions around the world. Additional Protocol I (1977) to the 1949 Geneva Conventions established a duty for state parties to cooperate by acting, individually or jointly, to address serious violations committed in the context of an international armed conflict in cooperation with the United Nations (Article 89). The 1951 Convention relating to the Status of Refugees requires that states provide asylum and ensure non-refoulement for people fleeing persecution because of their membership of a particular race, religion, nationality or social group or because or their political opinions (Article 33). The Arms Trade Treaty prohibits the sale of arms in situations where a State Party 'recognizes that that the arms or items would be used in the commission of genocide, crimes against humanity, grave breaches of the Geneva Conventions of 1949, attacks directed against civilian objects or civilians protected as such, or other war crimes' (Article 6.3).

This idea - that states have positive duties towards outsiders - is not new. As Luke Glanville recently pointed out, as early as the eighteenth century, Vattel pointed out that states had "duties 
to contribute to the perfection of those beyond their borders insofar as they can without doing an "essential injury" to themselves." 4

Four: Acknowledgement by the UN Security Council that genocide and mass atrocities constitute a threat to international peace and security, and therefore falls under the purview of international society's collective security system. Starting in 2001 with Sierra Leone and accelerating markedly after the adoption of the Responsibility to Protect principle in 2005, the protection of civilians from genocide and mass atrocities has moved from the periphery of the Council's agenda to its very core. Today, more than 100,000 UN peacekeepers are deployed around the world with Chapter VII enforcement mandates to protect civilians from atrocities. More broadly, the Security Council's recognition of genocide and mass atrocities as a threat to peace has had two profound effects on its practice. On the one hand, the likelihood of Council adopting measures in response to massacres has doubled since the end of the Cold War. On the other, the nature of these responses has grown steadily more comprehensive and multifaceted, with protection at their core.

Five: The development of international criminal justice. The International Criminal Court and other criminal tribunals are important for ensuring legal accountability for crimes and addressing impunity.

Six: The codification of human rights and establishment of national, regional and international institutions to promote and protect them. We must be mindful of where genocide begins. Genocide and mass atrocity crimes are extreme forms of identity-based violence. Their prevention therefore entails the elimination of the discrimination, hate speech and incitement that can give rise to identity conflict and mass violence - precisely one of the main focuses of international human rights law and the institutions that have been developed to promote and protect it. Legal obligations extend to addressing some of the root causes of atrocity crimes. In this context, among the most important are those international treaties that address entrenched patterns of discrimination, whether on grounds of nationality, ethnicity, religion, gender or other forms of identity. Most national constitutions and legal codes include provisions guaranteeing the fundamental rights of populations, such as equality before the law. States are also required to combat advocacy of national, racial or religious hatred that constitutes incitement to discrimination, hostility or violence, in line with Articles 19 and 20 of the International Covenant on Civil and Political Rights.

Seven: The development of international legal and institutional regimes focused on specific vulnerabilities, including those faced by refugees, displaced persons, people with disabilities, women and girls, and children more broadly. This includes efforts, albeit nowhere close to fully realized, to empower women as agents of protection.

Eight: The political commitment to the Responsibility to Protect (R2P) in 2005 and its implementation thereafter. In a sense, R2P clarifies the protection regime itself. R2P is a disarmingly simple idea. It holds that sovereign states have a responsibility to protect their own populations from four crimes that indisputably 'shock the conscience of humankind': genocide, war crimes, ethnic cleansing and crimes against humanity. It requires that the international community assist individual states to fulfill their responsibility, because some states lack the physical capacity and resources of legitimacy needed to protect their populations from these crimes. Finally, R2P says that when states are 'manifestly failing' to protect their populations from these four crimes, whether through lack of capacity or will or as a result of deliberate intent, the international community should respond in a 'timely and decisive' fashion with diplomatic, humanitarian and other peaceful means and, failing that, with all the tools that are available to the United Nations (UN) Security Council. R2P calls specifically for the prevention of the four crimes and - significantly their incitement.

These eight streams were developed separately at different times and without specific regard for the broader whole. But it was their collective force that made a difference, beginning in earnest only after the Cold War. Along with structural forces such as state consolidation, economic growth and trade, and factors that Azar Gat conjoins under the rubric of 'modernization,' these barriers to

\footnotetext{
${ }^{4}$ Luke Glanville, “Responsibility to Perfect: Vattel's Conception of Duties Beyond Borders," International Studies Quarterly 61, no. 2 (2017), 385.
} 
genocide and mass atrocities began to effect patterns of violence in earnest in the 1980. Genocide and mass atrocities were forced into decline. ${ }^{5}$

RJ Rummel's multiple surveys of 'democide' - the mass killing of people by their own government - in the twentieth century show a clear pattern of decline from a peak around the time of the Second World War. ${ }^{6}$ This general trend is also found in the data presented by the Political Instability Task Force (PITF), which focuses on the incidence of government sponsored mass killings and shows a sustained decline since 1993. ${ }^{7}$ The Uppsala Conflict Data Program (UCDP) and the 2013 Human Security Report presented a similar view that showed a steady decline in the number of cases from a peak in 2001 and a decline in the number of violent deaths globally. ${ }^{8}$ There were especially marked declines in the Americas, Central and South Asia, East Asia and Oceania, Europe, and sub-Saharan Africa. The normative developments charted earlier reshaped our expectations about how the world ought to respond to genocide and mass atrocities. We think we fail so much nowadays at least in part because we expect so much more than we once did.

It bears remembering that in the wake of Nuremberg, Rafael Lemkin lamented that had Nazi Germany exterminated only German Jews, it would have committed no international crime. ${ }^{9}$ Today, however, genocide, war crimes, and crimes against humanity are recognized as international crimes; states have positive legal, political and moral duties to prevent them and offer assistance across borders; the UN Security Council understands these to be matters of international peace and security falling within its purview; and a range of national, regional and international institutions have been established to assist states and to hold them to account.

But the struggle against atrocities is in crisis. The barriers to genocide erected in the decades after the Holocaust are being torn down.

\section{The Revenge of History}

Since 2011, genocide, mass atrocities, armed conflict, and global displacement have all moved in the wrong direction, prompting expressions of concern and alarm. After declining some $72 \%$ after 1990, the number of major civil wars grew from four to eleven after 2011, with the cumulative battle deaths reaching levels in 2014 and 2015 not seen since the end of the Cold War. ${ }^{10}$ Minor civil wars have also increased, reaching a level not seen since the mid-1990s. From the use of chemical weapons against civilians in Syria, to the brazen atrocities committed by violent extremists in Syria and Iraq and the indiscriminate use of air power against civilian populated areas in Syria and Yemen, the deliberate targeting of civilians and violation of International Humanitarian Law has become a regular feature of many modern armed conflicts. Reported attacks on protected buildings, such as hospitals and schools, and on protected persons such as humanitarian workers have increased. The besieging of civilian communities, denial of humanitarian relief and use of civilians as human shield have become commonplace features of the modern battlefields in places such as Aleppo and Mosul.

In Syria and Yemen, the situation of civilians besieged or otherwise unable to flee conflict zones has become so dire since 2015 that many have reportedly confronted the very real danger of starvation and often die for want of basic medical assistance. Indeed, the eradication of starvation - a genuine human achievement of the past few decades - is now at risk as a result of the march of mass atrocities.

\footnotetext{
${ }^{5}$ Azar Gat, The Causes of War and the Spread of Peace (Oxford: Oxford University Press, 2017).

${ }^{6}$ Rudolph J. Rummel, Death by Government (Piscataway: Transaction, 1994); Rudolph J. Rummel, Statistics of Democide (Piscataway, NJ: Transaction, 1997).

${ }^{7}$ Benjamin A. Valentino, "Why We Kill: The Political Science of Political Violence against Civilians," Annual Review of Political Science 17 (2014), 100.

${ }^{8}$ Human Security Report, Human Security Report 2013: The Decline in Global Violence: Evidence, Explanation and Contestation (Barnaby: Simon Fraser University, 2013), 107.

${ }^{9}$ Samantha Power, A Problem from Hell: America and the Age of Genocide (New York: Basic Books, 2002), 49.

${ }^{10}$ Uppsala Conflict Data Program and Peace Research Institute Oslo, UCDP/PRIO Armed Conflict Dataset, version 4-2016.
} 
Global trends show a sharp increase in 'one-sided' violence against civilians, beginning in 2013; and whilst atrocity crimes declined in 2015 from their peak a year earlier, they remained at levels not seen since 2001. ${ }^{11}$

To understand precisely what is going on, we need to understand that violence is driven by different concerns in different contexts. Foremost amongst the drivers of our more violent world is the lethality of new armed conflicts in the Middle East, in particular in Syria but also in Iraq and Yemen. The underlying causes of the armed conflicts that today plague the Middle East lay in crises of governance caused by the failure of authoritarian rulers to legitimize their rule or improve the lives of their populations and by the repeated self-interested interference of outside powers. They were triggered by forces unleashed by the 2003 US-led invasion of Iraq and 2011 Arab Spring.

Confronted by internal demands for reform, governments turned their guns on their own populations. Rebellions in Syria, Iraq and Yemen were all caused and then escalated by systematic discrimination against and violent abuse of individuals and groups not aligned to the government. They were further fuelled by external actors looking to exploit instability for their own advantage. In all of these conflicts, the deliberate targeting of civilians has been justified through the articulation of violent extremist ideologies that make no distinction between soldiers and civilians, ideologies that have gained in strength as the cycle of violence has escalated.

The second cluster of violence relates specifically to the rise of violent extremism in the Middle East, parts of sub-Saharan Africa (parts of Nigeria, Somalia, Mali), parts of central Asia (Afghanistan and parts of Pakistan), Europe, and parts of Southeast Asia (Myanmar and The Philippines). Violent extremist violence unleashed by Islamist non-state armed groups such as 'Islamic State,' al-Qaeda and its affiliates, Boko Haram and al-Shabaab overtly challenge established international norms and openly advocate atrocity crimes. Responses to violent extremism have also sometimes been quite bloody themselves. For example, since 2011, Boko Haram has been responsible for more than 11,000 deaths, more than 6,000 of which resulted from one-sided massacres of civilians. The Nigerian government's response has been no less brutal. Some 7,000 Boko Haram suspects have died in custody during that time. ${ }^{12}$

Many of these conflicts have their roots in specific localities. For example, it was a combination of local political intrigues and heavy handed policing that transformed Boko Haram from a small extremist sect into an armed militia capable of withstanding the attentions of the Nigerian army. In these contexts, political entrepreneurs exploit ethnic and religious divisions for their own ends and have developed extremist anti-civilian ideologies that reject fundamental principles of common humanity.

The third cluster of crises predates 2011 but remain unresolved. Conflicts in South Sudan, Sudan, Somalia, the DRC, Nigeria, CAR, Mali and Myanmar may have experienced peaks of violence in the past few years but their origins and much of their violence predate 2011. Colonial orders have yet to be fully replaced by legitimate state institutions capable of imposing the rule of law across their entire territory. Here, the rule of law is weak, and factions struggling for power have committed atrocity crimes and have sought to advance the interests of one part of the community at the expense of others.

The scale of these crises has been exacerbated by two further factors. First, declining international resolve to stop them. States of all stripes are seemingly less willing to uphold their legal obligations and shared responsibilities by acting collectively to prevent genocide and mass atrocities or respond to them by protecting populations in a timely and decisive fashion. There is evidence of declining compliance with fundamental tenets of International Humanitarian, Human Rights and Refugee Law, not just by the violent extremists and authoritarian states that perpetrate atrocity crimes but also by states of good standing and even some champions of human protection. In the face of the crisis of human protection described earlier, some states have wound back their commitment to crucial norms and principles. The Trump Administration, for example, has eased targeting restrictions aimed at protecting civilians from indiscriminate or disproportionate attacks.

\footnotetext{
${ }^{11}$ Eric Melander, Therese Pettersson and Lotta Themner, “Organised Violence, 1989-2015," Journal of Peace Research 53, no. 5 (2016), 617-631.

${ }^{12}$ Wisdom Oghasa Iyekekpolo, “Boko Haram: Understanding the Context," Third World Quarterly 37, no. 12 (2016), 2211-2228.
} 
Several others, including Hungary and Australia, have adopted refugee policies, which, the UNHCR believes, contradicts their legal obligations under the Refugee Convention and associated protocol. Burundi has withdrawn from the International Criminal Court, and South Africa and The Gambia threatened to do likewise, placing this new institution under immense political pressure. Others, such as The Philippines, could follow suit largely because the Court has become an inconvenience.

Foreign actors have also played significant roles in stoking some of the violence. Whilst, for example, the principal blame from the carnage in Syria must reside with the Syrian government we must also recognize that a number of states and other actors actively fuelled the conflict and encouraged its escalation. This includes Saudi Arabia, Turkey, Qatar, Iran, Hezbollah, Russia, and increasingly the US, but also - though to a lesser extent - the UK and France. There has been a significant increase in the involvement of outside states in civil wars. In 1990, only $4 \%$ of civil wars were "internationalized" through the direct involvement of other states. By 2015, that figure had increased to $40 \% .{ }^{13}$ Many of these civil wars were characterised by mass atrocities and experienced interventions by multiple external states. Some of these external actors - such as Russia in Syria and Saudi Arabia in Yemen - have used force in support of actors responsible for widespread and systematic atrocity crimes, have supported such uses of force, and have themselves directed attacks that have resulted in large-scale civilian casualties. Some of these attacks, such as the Russian bombing of a UN aid convoy in Syria in September 2016 and repeated Saudi bombing of schools and hospitals in Yemen, may in themselves constitute war crimes. These and other states have supplied the arms and ammunition used to commit atrocity crimes or have turned a blind eye to their transportation to the perpetrators of atrocities - in contravention of the spirit and letter of the Arms Trade Treaty. What is more, in Syria and Yemen, the scale of mass atrocities crimes is at least in part due to the sense of impunity granted to perpetrators by their Great Power allies: Russia in the case of the Syrian government, and the US in terms of the Saudi-led coalition in Yemen and Iraq. These states have inhibited accountability for atrocity crimes in the Middle East.

\section{Causes}

Why has the world taken this turn towards the more violent? One of the most popular theories is Pankaj Mishra's thesis that what we are seeing is merely the latest phase of a backlash against modernization and globalization. ${ }^{14}$ Mishra maintains that Western style modernization uprooted traditional cultures and societies but failed to replace them with new locally grounded and legitimated ideas about how we should live. That was not much of a problem for those who benefitted materially from the global transformation but it created a reservoir of resentment amongst those who did not benefit, those on the receiving end of the ever-widening inequalities between rich and poor. Extremist ideologues - entrepreneurs of disenchantment - exploited this resentment to their own advantage. Romantics responded to modernity with nationalism and mythology; anarchists, communists and fascists with wildly utopian visions of a world reordered; Islamists with dreams of the caliphate and the restoration of their own - extremist - accounts of sha'ria. In Mishra's vision, today's jihadists and white extremists are simply contemporary manifestations of the same forces that brought anarchist terrorism, socialism and fascism to the streets of Europe in the nineteenth and early twentieth centuries.

This account is illuminating inasmuch as it points to the inevitability of violent resistance to transformational change and shows that far from being unique and novel, the extremism of today draws from the same reservoirs of human resentment that drove extremism a century ago. But it is a one-sided accounting that pays little attention to the goods wrought by modernization, not least among them sharp declines in poverty, and increases both the quality and length of life. It is also too general in its explanation. It struggles to explain why this type of violence emerged in some times and places and not others undergoing similar transformations. Here, I suspect that the ideologues play a more significant role than this account suggests.

So too do local conditions. The rise of Boko Haram, for example, had next to nothing to do with

${ }^{13}$ UCDP/PRIO Armed Conflict Dataset, version 4-2016.

${ }^{14}$ Pankaj Mishra, Age of Anger: A History of the Present (New York: Farrar, Straus and Giroux, 2017). 
industrialization and modernization and everything to do with local politics and the authorities' mistreatment of opposition activists. Likewise, it was not 'modernization' that sparked the Sunni rebellion in Iraq that eventually gave rise to Islamic State. After all, many of Iraq's Sunnis had profited under Saddam's modernization schemas. Rather, it was the collapse of Saddam's regime, their loss of privilege, wealth and security, and the sometimes brutal discrimination against them by the Shi'ite controlled government in Baghdad that drove their resentment: products of the US decision to invade in 2003.

An alternative account suggests that the problem lay not in the fact of violence, but rather in our interpretation of it. That is, the elevated normative expectations I mentioned earlier were not, as it was claimed, products of a universally understood conception of humanity and human rights but rather of a liberal moment in world politics made possible by Western hegemony after the Second World War and its triumph after the Cold War. As EH Carr explained in 1939, perhaps the 'common morality' that underpinned the struggle against genocide after the Holocaust was actually nothing more than the interests and preferences of the powerful masquerading as universal moral truth..$^{15}$ If Carr was right, then important elements of the struggle against genocide - human rights and humanitarian law, human rights institutions, R2P, international criminal justice - might be better understood as products of a Western liberal governed international system rather than normative standards genuinely shared by the society of states. And, if that is correct, the relative decline of the West should result in the relative decline of Western liberal values measured in terms of declining compliance and the declining will and capacity of states and institutions to ensure compliance. From this perspective, we are witnessing end times of human rights, as Stephen Hopgood eloquently explained. ${ }^{16}$

I have always baulked at the association of the West with liberalism and fundamental ideas about human rights, not least because it exaggerates the extent to which Western states actually championed these rights and also because it simultaneously neglects the ideas, struggles and advocacy of non-Western leaders, activists and communities. The campaign against colonialism was prefaced on the idea all humans enjoyed certain fundamental rights, not least to life and liberty. Western states were among those most implacably opposed to these notions. It was African and other post-colonial states, that argued - in the context of apartheid South Africa - that governments were not entitled to discriminate on the grounds of race or to treat their populations however they saw fit; arguments which at the time often met opposition in the West, not least the US and UK. More recently, R2P was devised by a commission co-chaired by an Algerian (Mohammed Sahnoun), placed on the UN's agenda by a Ghanian (Kofi Annan), and negotiated by a General Assembly led by a diplomat from Gabon. Rwanda, South Africa and Pakistan played pivotal roles in those negotiations. It was Guatemala that proposed the UN General Assembly's first resolution affirming the principal, over the objections of many European states. In all this, it bears remembering that John Bolton - the US Ambassador to the UN at the time - remained implacably opposed to the concept and that by the time that the UN got around to adopting R2P, the African Union had already adopted more forceful language on atrocity responses into its own constitution. The same is true of other institutions. There was little diplomatic pressure, and certainly no coercive inducement, placed on states to agree, sign and ratify the Rome Statute of the ICC. The US, recall, is not a state party.

Treaties, resolutions and positions have to persuade a majority of states to be adopted by the United Nations. It is a long time since the West had the numbers to control a majority in the UN. But that is precisely why Carr's diagnosis of 'moral universalism' as simply the preferences of the powerful is not an accurate description of our context today. Only those ideas that command a majority drawn from every part of the world can advance. Most, if not all, of the legal and institutional barriers against genocide have commanded a sustained majority. They are, I think, signifiers of an 'overlapping moral consensus' against genocide and mass atrocities, not a thinly veiled Western moral hegemony.

\footnotetext{
${ }^{15}$ Edward Hallett Carr, The Twenty Years Crisis: Introduction to International Relations (London: Papermac, 1987 [1939]), $42-43$.

${ }^{16}$ Stephen Hopgood, The Endtimes of Human Rights (Ithaca: Cornell University Press, 2013).
} 
Setting these two explanations alongside one another does highlight one critical point: our explanation of the present must address two distinct problems: why is violence increasing and why is international society seemingly less able to control it? In relation to the first question, Mishra's account exposes how radical social and economic transformations can give rise to violent backlashes though it was not always modernization that lay at the heart of the problem: local politics and foreign invasions have proven equally significant in recent rimes. Nonetheless, fragmentation, inequality, instability and ideology provide us with a useful way of understanding violent extremism.

But violent extremism is only one of the things making our world more violent. Another, is the incomplete globalization of international society. By this, I mean the project of establishing a global order comprised of sovereign states capable of maintaining order within their boundaries without having to resort to mass violence. Many of the conflicts that give rise to genocide and mass atrocities today might be characterized as wars of state formation and consolidation - wars about what the boundaries of the state should be, what ideological and constitutional form it should take, and who should control it and on what basis. Of these many occur in countries where the states have barely - if ever - exercised legitimate control over the whole of their territory. In Sudan, South Sudan, Somalia, DRC, CAR, Mali, and Myanmar there have been many more years of war than of peace since independence and atrocity crimes have been longstanding features of these wars in part because of their practical utility and in part because the association of peoples and territories lay at their core. But in addition to these residual conflicts, the 'Arab Spring' gave rise to a new set of conflicts, caused in part by the failure of the Middle East's authoritarian governments to build internal legitimacy and improve the lives of their peoples and in part by external intervention.

This is happening in an era of declining internationalism, in which, as Peter Hayes put it, 'onlookers [are too] preoccupied with their own, to them more pressing concerns' to do what is necessary to protect shared international norms ${ }^{17}$ This is a trend driven in part by stagnating and declining economies in the post Global Financial Crisis world, which has prompted governments to look inwards rather than outwards. These sentiments have encouraged states to retreat from the active promotion of global anti-atrocity norms abroad, with two principal effects. First, by reducing expectations of foreign intervention, sanctions or censure, retreating internationalism has altered the balance of costs and payoffs associated with mass atrocities in favour of the payoffs. On the costs side, the chances of prosecution, intervention, sanctions and embargoes have declined. On the payoff side, the chances of foreign support for perpetrators have increased in some cases. Second, the decline of internationalism has elevated suffering by limiting the aid granted to vulnerable populations and the survivors of mass violence. Such heightened suffering will only add to the reservoir of resentment from where the ideologues of extremism draw their support.

\section{Response}

What then is to be done? Our response to these challenges should be built on rights, collective action and accountability. The fundamental human right to be protected from genocide and other mass atrocity crimes must be at the heart of what we do. The reaffirmation of rights is central both to delineating the bounds of acceptable and unacceptable behavior and in reframing the language we use to describe situations and the peoples affected by them. Genocide and mass atrocities are crimes and need to be explained as such. The victims of these crimes are not only just that - victims of crimes - but also rights-bearing individuals deserving of protection. This needs to be our starting point - the satisfaction of fundamental, universal and very basic human rights.

With that in mind, we need to reaffirm faith in fundamental human rights. We need nothing short of a global campaign to ensure that people know of their rights, understand why they have them and how they arose, and to ensure that government fulfills its most basic of duties: the provision of order and protection from the violation of fundamental rights. As a start, we need to persuade states to sign, ratify and implement the key international treaties and protocols associated with the prohibition and prevention of atrocity crimes and provision of assistance to their victims.

${ }^{17}$ Peter Hayes, Why? Explaining the Holocaust (New York: W. W. Norton, 2017), xv. 
Member States should also ensure that atrocity crimes and their incitement are criminalized by domestic law. To encourage them to do so, we need a global campaign to reaffirm the world's commitment to the core obligations of International Humanitarian and Human Rights Law.

The second step is to translate abstract agreements, principles and articles of faith into collective action. Global thought on the prevention of genocide and mass atrocities remains too abstract and generic, which consequently limits its capacity to shape behavior and impel collective action. States are typically risk averse, meaning that it is easier to persuade them to act after the fact, when costs and consequences can be calculated and causation attributed than it is to persuade them to act prospectively. We need then to think more carefully about the politics and practices of collective action. To think in more tangible terms about how to prevent this specific genocide rather than genocide in practice; to identify which capabilities are needed for what job, and which need strengthening, and how. We need to better at figuring out what political claims and maneuvers are required to protect people and what is realistically achievable, and about what capacities are required and how, precisely, they can be built. For example, the UN Secretary-General could utilize his annual report to member states on R2P to articulate a clear strategy for atrocity prevention. National governments could take steps to mainstream atrocity prevention concerns into their foreign and development policies. There is also a need for stronger research on atrocity prevention. We need to better understand the precise preventive strategies, policies and levers of influence that can be used, and by who, to address specific threats and risks.

Political leadership is also imperative. We need political leaders willing to support global efforts against genocide and mass atrocities and prepared to take risks to advance them. New leadership will have to come from outside the West. For example, rather than resisting Chinese pretensions to leadership through the UN, the West should embrace it and explore ways of transferring greater responsibility for international peace and security to it. My main point here is that the traditional friends of human protection will need to do more to encourage others to take the lead and should be prepared to transfer responsibility to others.

Finally, accountability is needed to close the gap between normative commitments, legal obligations and actual lived reality. International organizations, governments, individual leaders, and state agents have specific - individual - responsibilities and obligations related to the protection of populations from genocide and mass atrocities. We must work to make them more accountable. Accountability helps close the gap between commitment and lived reality by ensuring the rigorous and open scrutiny of practice in light of agreed principles.

Individual states must be held accountable to their own societies and their peers to ensure that they fill their core protection obligations. We need research and activism to ensure that states establish domestic mechanisms to ensure that national authorities are accountable for their commitment to the Responsibility to Protect. This could be achieved through regular parliamentary debates, permanent parliamentary working groups, annual reports by National Human Rights Institutions or Human Rights Ombudspersons, or other mechanisms such as national committees for atrocity prevention. We need nothing short of a new domestic politics in each country, one that demands action to fulfill the solemn commitments and legal obligation of states.

\section{Conclusion}

There is no doubt that the struggle against genocide and mass atrocities confronts a major crisis. Part of this is simply a function of the increase in global violence. But there are also powerful global trends pushing against human protection, forces of racism, nationalism, xenophobia, and extremism. But the greatest strength of the barrier erected against genocide after the Holocaust is the sustained global consensus on which it rests. Different cultural traditions have their own expressions of human protection. To borrow a label from John Rawls, on this we have a point of "overlapping consensus" between the world's many different conceptions of justice. ${ }^{18}$ With so much normative and political progress made, the challenge now is to make atrocity crimes prevention a lived reality and to turn back the tide of violence sweeping the world. We can all play

${ }^{18}$ John Rawls, Theory of Justice (Cambridge: Harvard University Press, 1971), 340. 
a role whether by defending internationalism, filling the knowledge gaps that will help drive better informed practice, or by providing the fresh ideas that are sorely needed.

There remains too much of a gap between the solemn commitments and legal obligations of States and the actual lived experience of vulnerable populations. As the new UN SecretaryGeneral, Antonio Guterres told the Security Council in early 2017, "Our failure to deliver on what we have promised by protecting populations from atrocity crimes shames us all. We must do better." 19 Indeed, we must.

\section{Bibliography}

Bellamy, Alex J. "The Humanization of Security: Towards an International Human Protection Regime." European Journal of International Security 1, no. 1 (2016), 112-133. https://doi. org/10.1017/eis.2015.5

Carr, Edward Hallett. The Twenty Years Crisis: Introduction to International Relations London: Papermac, [1939] 1987.

Ceadal, Martin. Thinking about Peace and War. Oxford: Oxford University Press, 1987.

Evans, Gareth. The Responsibility to Protect: The Campaign to End Mass Atrocities Once and for All. Washington, DC: The Brookings Institution, 2008.

Gat, Azar. The Causes of War and the Spread of Peace. Oxford: Oxford University Press, 2017.

Glanville, Luke. "Responsibility to Perfect: Vattel's Conception of Duties Beyond Borders." International Studies Quarterly 61, no. 2 (2017), 385-395. https://doi.org/10.1093/isq/sqx018

Goldstein, Joshua S. Winning the War on War: The Decline of Armed Conflict Worldwide. New York: Dutton, 2011.

Guterrez, António. Maintenance of International Peace and Security: Conflict Prevention and Sustaining Peace. Remarks, New York, January 10, 2017. Accessed May 25, 2017. https://www.un.org/sg/en/content/sg/speeches/2017-01-10/secretary-generals-remarksmaintenance-international-peace-and.

Hayes, Peter. Why? Explaining the Holocaust. New York: W. W. Norton, 2017.

Hopgood, Stephen. The Endtimes of Human Rights. Ithaca: Cornell University Press, 2013.

Human Security Report. Human Security Report 2013: The Decline in Global Violence: Evidence, Explanation and Contestation. Barnaby: Simon Fraser University, 2013.

Iyekekpolo, Wisdom Oghasa. "Boko Haram: Understanding the Context." Third World Quarterly 37, no. 12 (2016), 2211-2228. https://doi.org/10.1080/01436597.2016.1177453

Melander, Eric, Therese Pettersson, and Lotta Themner. “Organised Violence, 1989-2015." Journal of Peace Research 53, no. 5 (2016), 617-631. https://doi.org/10.1177/0022343316663032

Mishra, Pankaj. Age of Anger: A History of the Present. New York: Farrar, Straus and Giroux, 2017.

Pinker, Steven. The Better Angels of our Nature: Why Violence has Declined. New York: Penguin, 2012.

Power, Samantha. A Problem from Hell: America and the Age of Genocide. New York: Basic Books, 2002.

Rawls, John. Theory of Justice. Cambridge: Harvard University Press, 1971.

Rummel, Rudolph J. Death by Government. Piscataway: Transaction, 1994.

-------. Statistics of Democide. Piscataway: Transaction, 1997.

Uppsala Conflict Data Program and Peace Research Institute Oslo. UCDP/PRIO Armed Conflict Dataset, version 4-2016.

Valentino, Benjamin A. "Why We Kill: The Political Science of Political Violence against Civilians." Annual Review of Political Science 17 (2014), 89-103. https://doi.org/10.1146/annurevpolisci-082112-141937

\footnotetext{
${ }^{19}$ António Guterrez, Maintenance of International Peace and Security: Conflict Prevention and Sustaining Peace, (remarks, New York, January 10, 2017), accessed May 25, 2017, https://www.un.org/sg/en/content/sg/speeches/2017-01-10/secretarygenerals-remarks-maintenance-international-peace-and.
} 